\title{
ARCHITECTURAL HERITAGE AT RISK: THE CASE OF THE MAGNANO HAMLET (PIEDMONT, ITALY)
}

\author{
F. Fratini ${ }^{1, *}$, M. Mattone ${ }^{2}$, S. Rescic ${ }^{1}$ \\ ${ }^{1}$ CNR-Institute of Heritage Science, Sesto Fiorentino, Italy - (fabio.fratini, silvia.rescic)@ cnr.it \\ ${ }^{2}$ Politecnico di Torino, Dipartimento Architettura e Design - manuela.mattone@ polito.it
}

Comission II - WG II/8

KEY WORDS: Architectural heritage, Risk, Preservation, Compatibility, Identity, Re-use

\begin{abstract}
:
The architecture is the result of the men's work, whose actions do not end with its construction, but are inevitably destined to follow one another over time, responding to the various natural and/or anthropic solicitations to which it is subjected. The progressive change in social and economic needs, together with the lack of recognition of the value of the inherited architectural heritage, causes an increasing pressure both on individual historic buildings and on ancient sites. Considered as obsolete and incapable of responding to current performance and functional requirements, the architectural heritage is often abandoned or subjected to radical transformations, causing the irremediable loss of valuable cultural resources. The examination of the current state of conservation of the Magnano hamlet is interesting for the purposes of 'Risk in architectural heritage'. It is a defensive settlement built at the beginning of the XIIIth century and characterized by the presence of building cells lying on the crest of a hill and surrounded by walls. Some of these cells are today totally abandoned and, therefore, affected by decay phenomena due to the aggressive action exerted by environmental agents; others have undergone interventions that, although aimed at allowing their possible re-use, have led to the partial or total loss of the identity features of this heritage. This paper intends to focus on the analysis of the interventions carried out, examining the methodologies adopted and some critical issues in the belief that only by searching for compatible solutions in terms of materials, structures and functionality, it is possible to become promoters of an effective conservation of the architectural heritage.
\end{abstract}

\section{INTRODUCTION}

Article. 30 of the Code of Cultural Heritage (2004) establishes that the State, the regions, the territorial public authorities as well as the private owners have to guarantee the safety and conservation of their cultural heritage properties.

According to the art. 29 of the aforementioned Code, conservation should be ensured "through a coherent, coordinated and planned study, prevention, maintenance and restoration". The latter is defined as "direct intervention on the asset through a complex of operations aimed at both its material preservation and recovery, and at the protection and transmission of its cultural values". However, the analysis of the current state of conservation of buildings belonging to the Magnano hamlet (Piedmont, Italy) highlights how these purposes have not always been pursued. Although the buildings of the hamlet have been subject to regulatory and restrictions since the early twentieth century (not. Min. 09/06/1908), sometimes the architectural assets have undergone interventions that have modified their identity and compromised their conservation over time. The progressive change of social and economic needs, together with the lack of recognition of the cultural value of the assets inherited from the past, determines increasing pressure both on single historical architectures and on ancient sites. Although the re-use of buildings, through the insertion of a new function or the continuation of the original one, is to be considered a mean through which ensure their conservation, often the intervention on the built determines its radical transformation (Fratini et al., 2019, Mileto, Vegas,
2007). The desire to make the architectural artefacts responsive to the changed functional and/or performance requirements determines the irreparable alteration of the testimonial value of valuable cultural resources. Existing buildings are made suitable for current days. Regrettably, their functional and environmental performances are often improved forgetting their historical and cultural value. Certainly, as Victor Hugo stated, architecture is a collective work, built over the long term thanks to the commitment of many generations. It is to be considered a "living work" and, as such, destined to undergo continuous changes over its existence. The signs left by modifications, which may be needed from time to time, testify to its evolution and, at the same time, its «vitality» (Vassallo, 2007). Projects on existing architectures should be drawn up taking care to control the needed changes. Interventions should be carried out promoting the objective of quality in contemporary additions without endangering the cultural value of the assets (Framework Convention on the Value of Cultural Heritage for Society, 2005).

The interventions should provide for the adaptation of the architectural artefacts to new functional and performance requirements, excluding interventions that could determine the alteration of the peculiar characteristics of the buildings (Acar Bilgin, 2019; Vegas, Mileto, 2015; AA.VV. 2014). It is in fact a matter of minimizing the modifications and/or destructions and of planning all the new interventions taking care to respect the signs of the past (Prajnawrdhi, 2020; Philokyprou, 2018; Dipasquale et al., 2016).

\footnotetext{
* Corresponding author
} 
This contribution aims at illustrating the results of an investigation conducted in Magnano's hamlet in order to highlight discrepancies between theoretical issues, regulatory requirements and operating practices. The latter testifies to a lack of respect for the identity characteristics of the architectural artefacts that are altered without identifying appropriate compromise solutions between functional requirements and conservation issues.

\section{THE MAGNANO HAMLET}

\subsection{Construction features and current state of conservation}

The Magnano hamlet, founded in 1204 (Viglino Davico, 1978; Settia, 1976), is a defensive settlement, created with the aim of guaranteeing the defence of the inhabitants and their assets from the sacking of armed gangs that crossed the countryside in medieval times. It is located in a dominant position on the external ridge of the Serra d'Ivrea, a relief belonging to the morainic amphitheatre formed thanks to debris transported to the Po valley by the large glacier that ran through the Dora Baltea valley during the Quaternary glaciations (Figures 1 and 2).

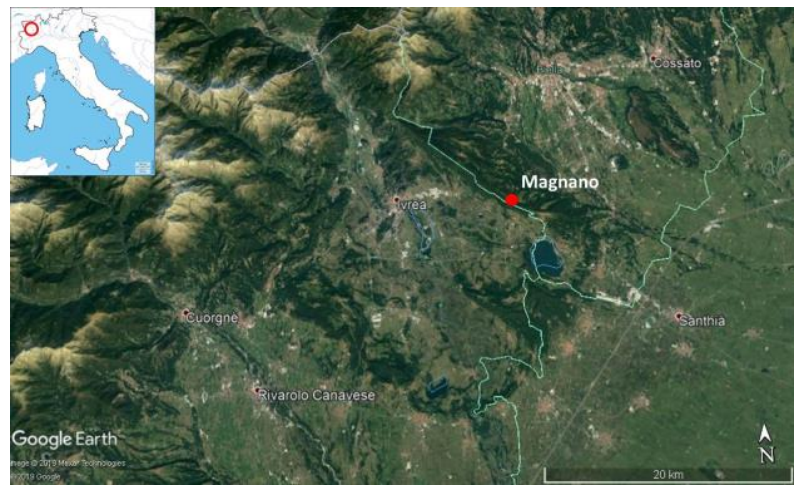

Figure 1. Position of Magnano on the outer ridge of the Serra d'Ivrea, in Piedmont (after Google Earth, modified).

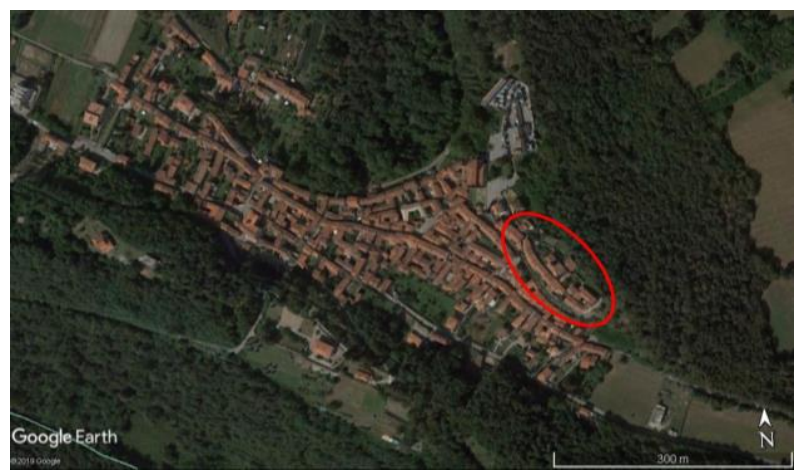

Figure 2. Position of the hamlet in the Magnano village (after Google Earth, modified).

The hamlet is characterized by the presence of building cells which, lying on the crest of a hill, are surrounded by defensive walls.

A tower-door equipped with a single arched driveway guarantees the access to the hamlet. The first part of the urban core is characterized by the presence of a single road axis on which there are few surviving buildings, mostly extensively transformed. Continuing east, the road branches off into three parallel streets, located at different altitudes (Figure 3).

These road axes delimit compact blocks, made up of small buildings. Where the building cell is located between two parallel axes, the particular shape of the land has been exploited to ensure direct access by road to both rooms that constitute the single construction (Figure 4).

The buildings have load-bearing walls made of stone and brick. The floors have a double wooden structure. The main beams are positioned parallel to the façade and act as a chain for the side walls.

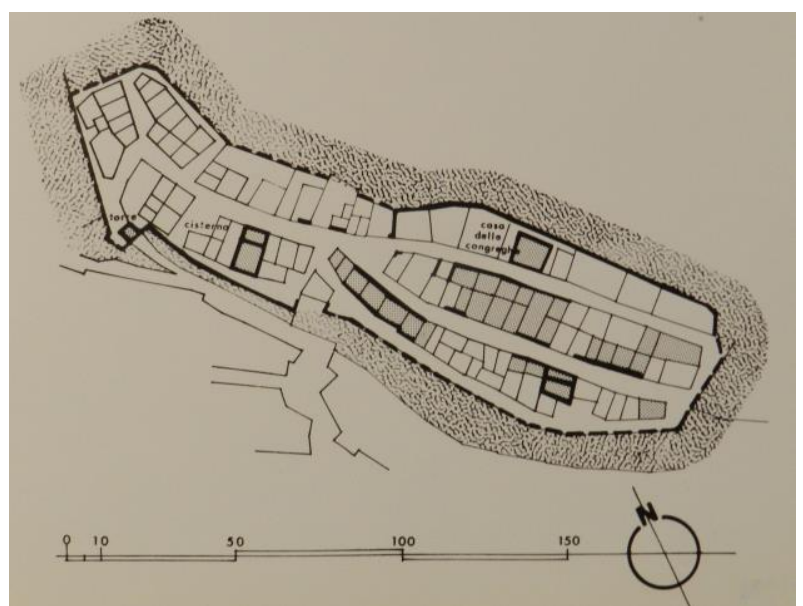

Figure 3. Planimetric layout of the hamlet in 1780 (after Viglino Davico, 1978).

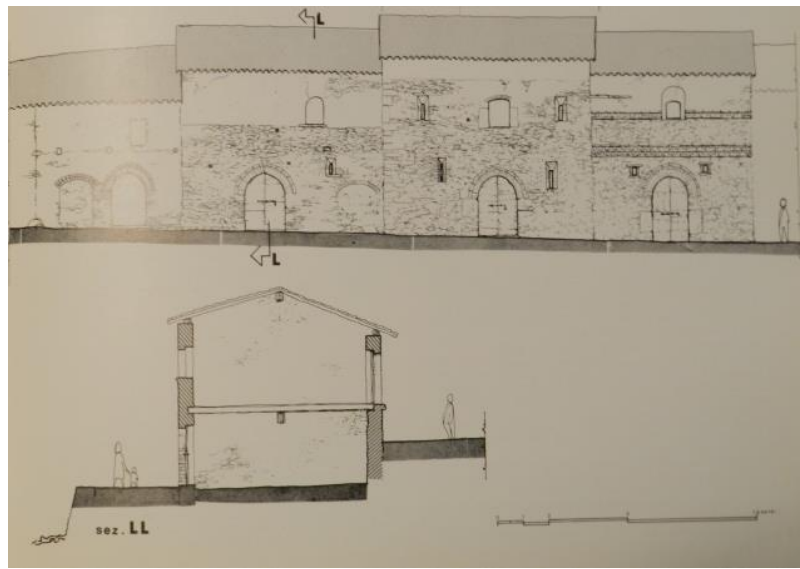

Figure 4. Elevation and section of some building cells (after Viglino Davico, 1978).

The openings are mostly delimited by fired bricks to be referred to interventions carried out in the XVth century on the existing wall structure (Viglino Davico, 1978). Sometimes, bricks are also used for decorative purposes: elements such as cornices and notches adorn some buildings' façade (Figure 5).

Except for some cases, the state of conservation of the constructions are rather critical. Those no longer used are turning progressively into ruins. Others underwent interventions which, although aimed at allowing their possible reuse, led to the partial or total loss of their identity.

Abandoned for years, some buildings are without roof and their stability is guaranteed through temporary static aids, positioned by the municipal administration in order to avoid their collapse (Figure 6).

Generally, the buildings used for residential purposes (permanent or temporary) are better preserved. However, because of the changing needs, lifestyles, aesthetic taste, many interventions have been done often significantly altering their identity characteristics. Subtraction, replacement and addition of parts were carried out without paying enough attention to the elements 
connoting the architectural artefacts. The consequence is the loss of their historical value. In some cases, interventions of integration and/or reintegration of the masonry were carried out attempting to re-propose without success materials and construction typologies similar to the original ones. The window frames have often been replaced changing the typologies and sometimes also the materials. In order to pursue higher energy performances, old roofs have been replaced by new and thicker ones altering the original proportions of the buildings.

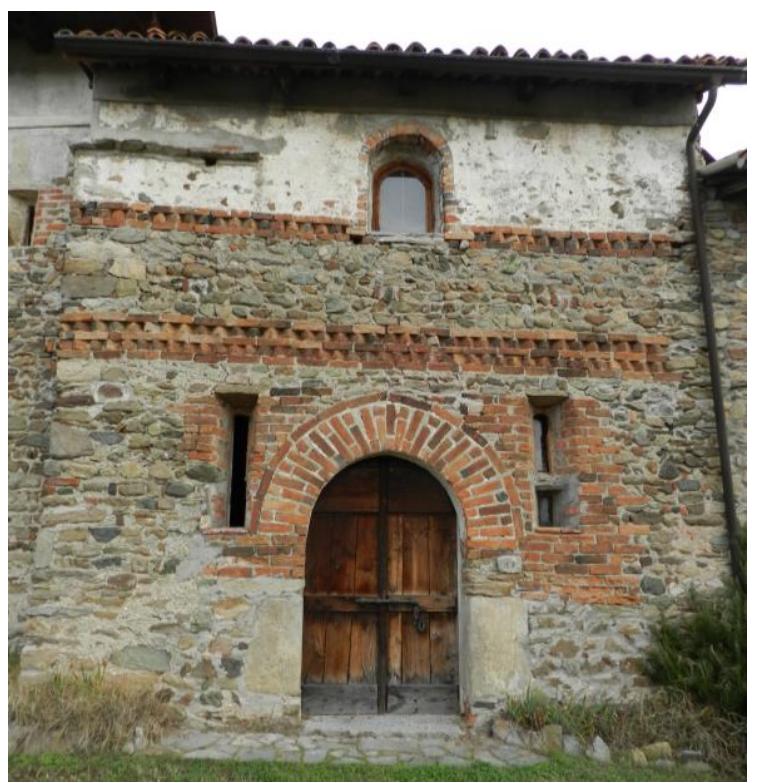

Figure 5. Brick decorative elements (credits Manuela Mattone).

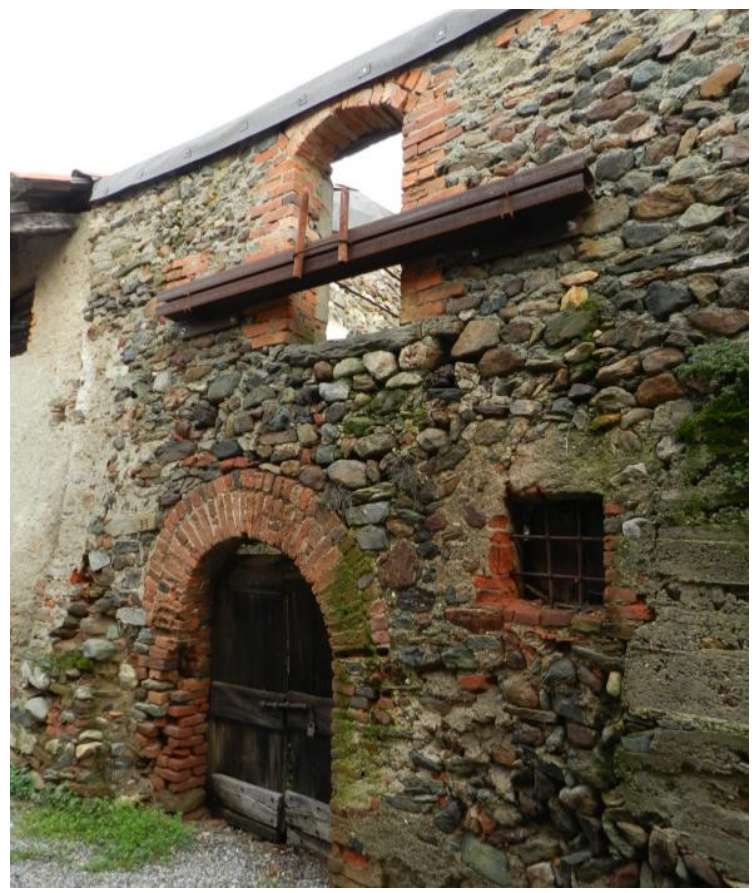

Figure 6. Building C - Temporary consolidation intervention carried out by the municipality (credits Manuela Mattone).

\subsection{Analysis of the interventions carried out in the Magnano hamlet}

The interventions conducted on some buildings leads us suppose a lack of shared guidelines aimed at fostering the design of appropriate actions. As a matter of fact, in many cases, actions not enough respectful of the historical and architectural values have been carried out causing damages and compromising the conservation of the assets through the use of inappropriate methodologies and incompatible materials (Musso, Franco, 2015). Some of these interventions are illustrated below, highlighting some the critical issues. The following table (Table 1) identifies the main causes of the lack of conservation of the buildings and the case studies examined.

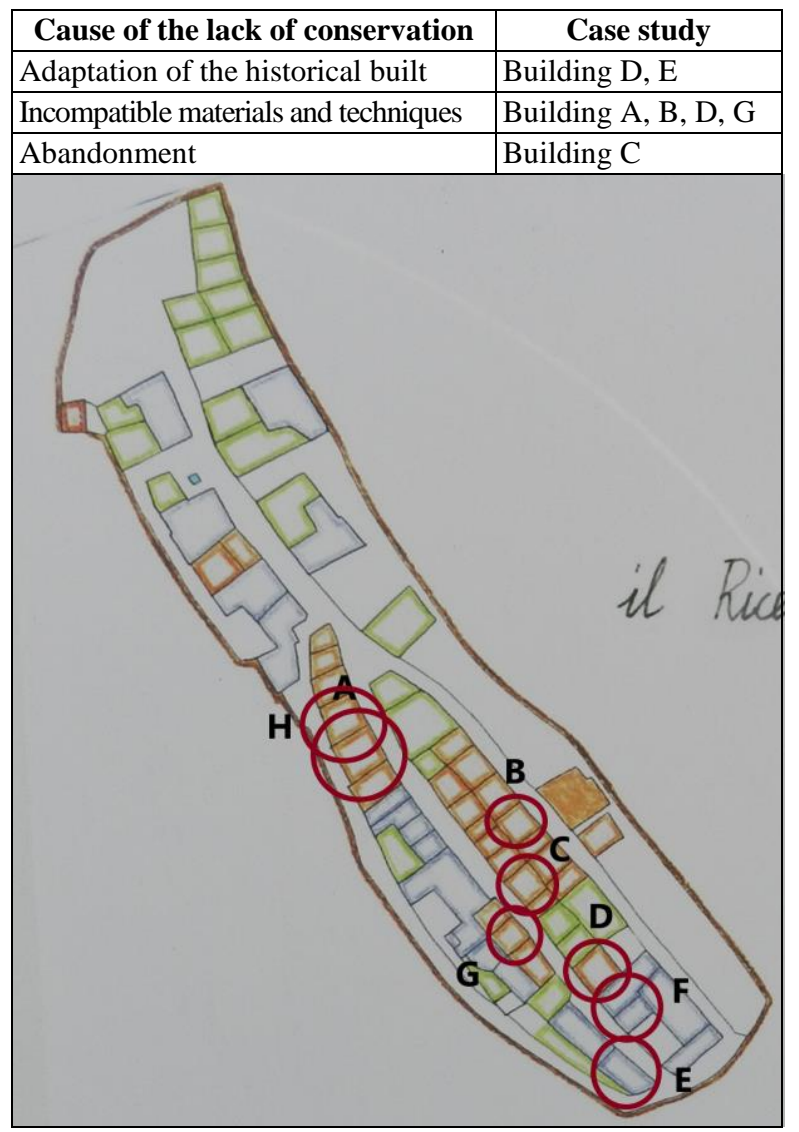

Table 1 . Case study localization

2.2.1 Adaptation of the historical built: Over time, some of the buildings of the hamlet have undergone interventions aimed at ensuring their re-use for residential purposes. They provided for the restoration of missing parts and the reshaping of the buildings in relation to aesthetic tastes and functional needs of the owners. Specific conservation requirements of the cultural heritage have not been sufficiently taken into account and interventions compromising its integrity and inherent values have been carried out. They led to a significant transformation of the buildings which often lost their specific features. The only recognised value was the use value, which lead to the adaptation of the built to changing conditions in order to make it able to suit the new needs. The insertion of balconies with reinforced concrete structure (Figure 7); the insertion of stone slab coverings along the baseboards and of ceramic tiles on the external floors (Figure 8); the addition of wooden battens in the overhang of the roof (Figure 9); the replacement of windows and the application of finishing plasters testify to the lack of attention towards the architectural heritage which is altered without paying sufficient attention to its historical-cultural as well as formal characteristics. Integrations and replacements are carried out by compromising the preservation of the architectural artefacts both at the typological and construction level and causing the irremediable loss of their identity. 


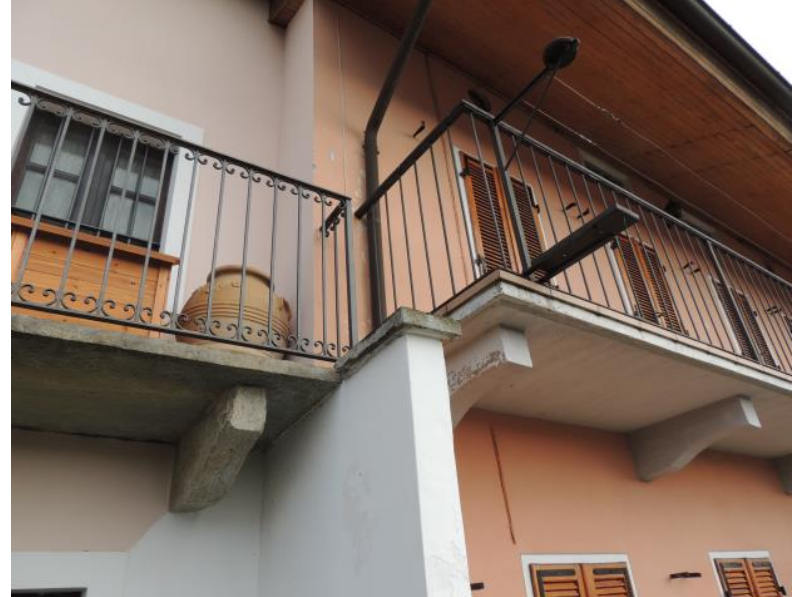

Figure 7. Building E - Balcony with reinforced concrete structure (credits Fabio Fratini).

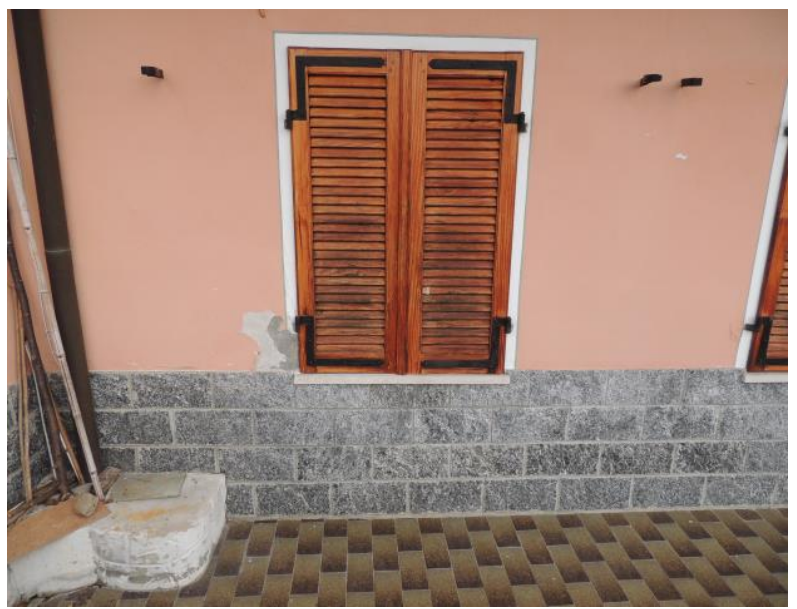

Figure 8. Building E - Baseboard in stone slabs and an external flooring in ceramic tiles, replacement of the windows and application of a new finishing layer (credits Fabio Fratini).

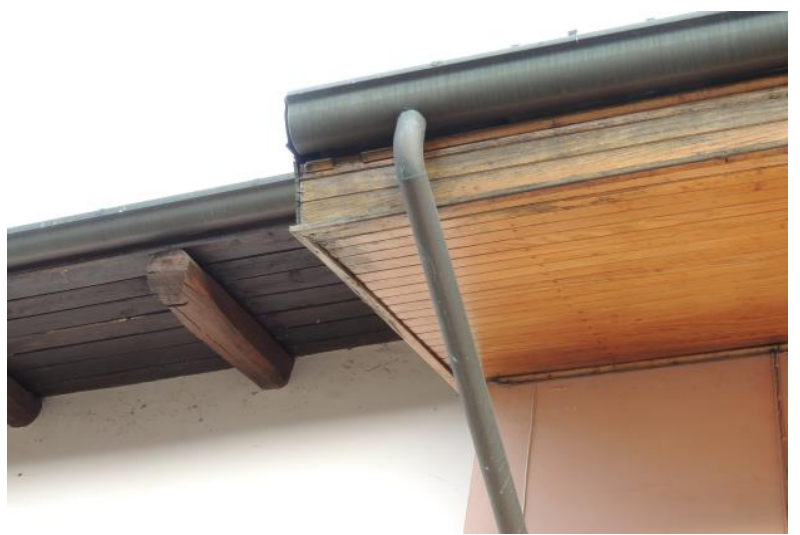

Figure 9. Building E - Wooden battens in the overhang of the roof (credits Fabio Fratini).

The same applies to restoration interventions that involve the reintegration of destroyed parts of the buildings such as walls, roofs, windows. Although the materials used are similar to the original ones, the treatment reserved for them is totally different. The methods of laying the stone and the bedding mortar change; the thickness of the roof is improved, presumably in relation to the desire to guarantee higher energy performances (Figure 10).

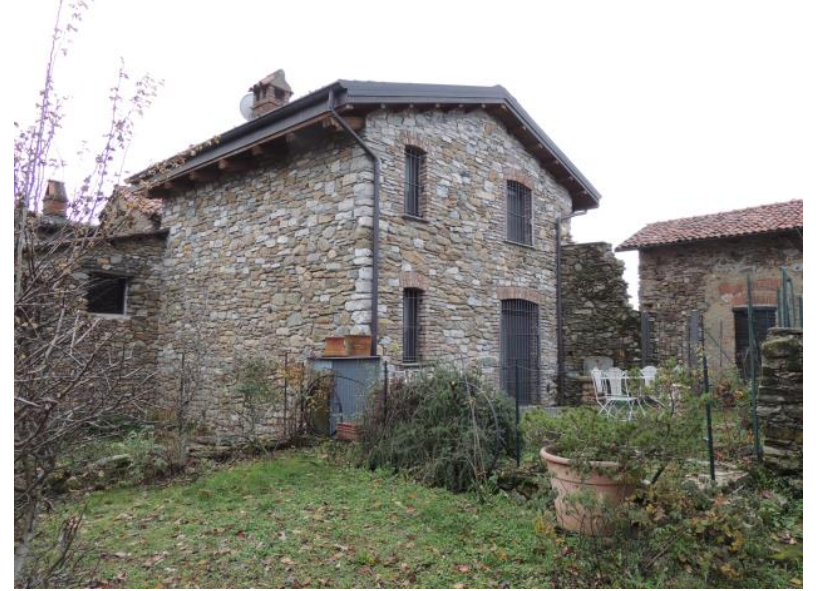

Figure 10. Building D - Reintegration of the upper part of the walls and of the roof (credits Manuela Mattone).

2.2.2 Incompatible materials and technique: Numerous inappropriate punctual interventions have also been done. Restoration of the walls has been often carried out using inadequate laying materials and methods. Particularly noteworthy is the widespread use of cement mortar not only for the bedding of bricks, but also for the reintegration of cracks and heavily eroded bricks (Figures 11 to 15 ).

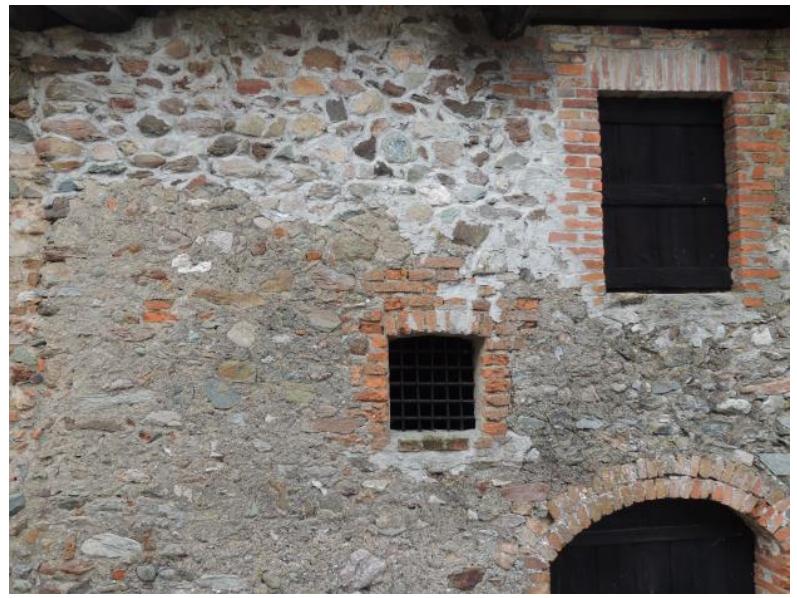

Figure 11. Building B - Reintegration of the masonry adopting inappropriate materials (credits Fabio Fratini).

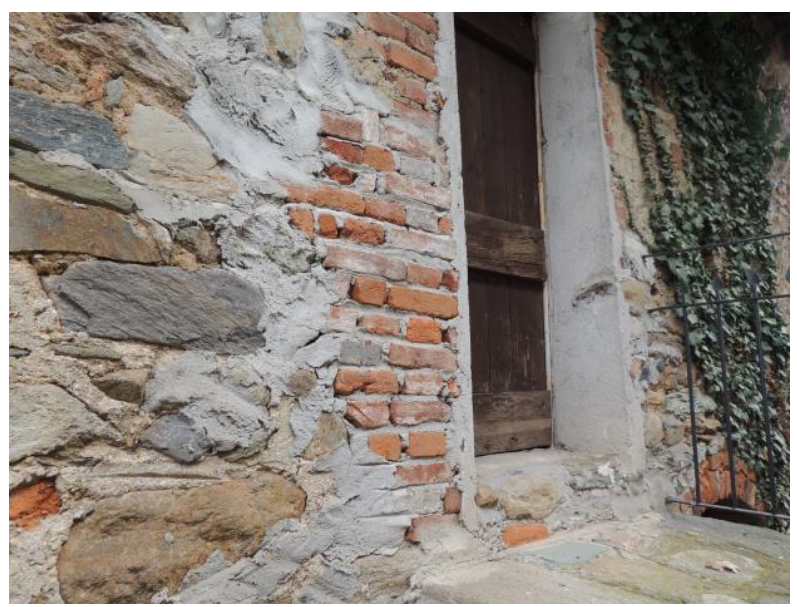

Figure 12. Building G - Improper intervention with cement mortar (credits Fabio Fratini). 


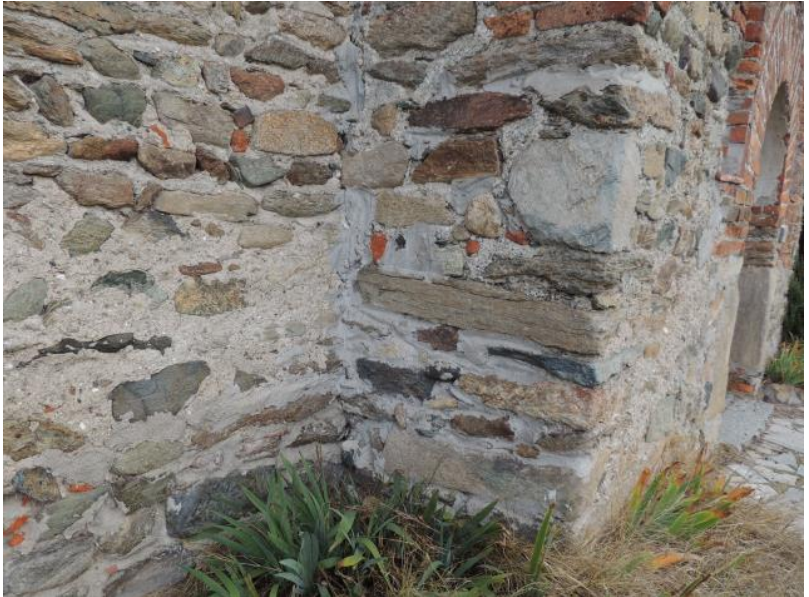

Figure 13. Building A - Grouting with cement mortar (credits Fabio Fratini).

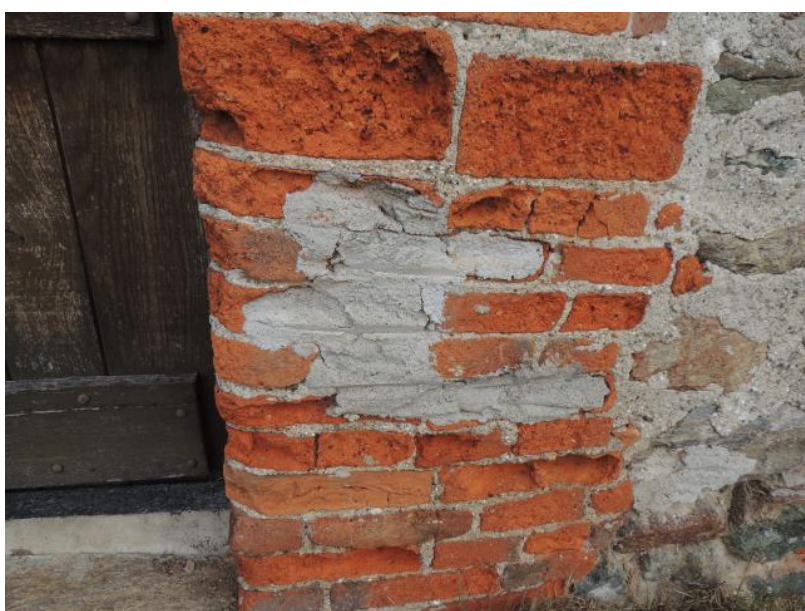

Figure 14. Building A - Reintegration of eroded bricks with cement mortar (credits Fabio Fratini).

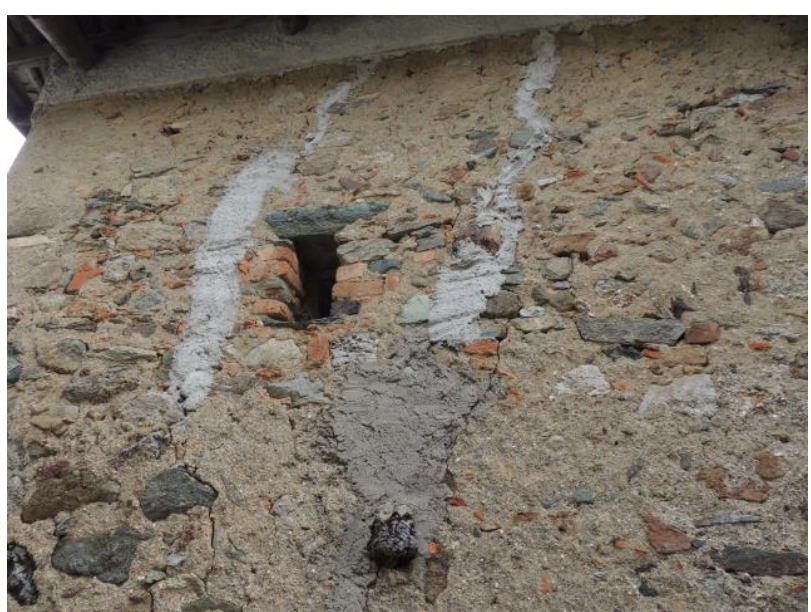

Figure 15. Building G - Filling of cracks with cement mortar (credits Fabio Fratini).

This intervention is incompatible not only from the mechanical point of view (elastic modulus of the whole), but also as regards the chemical (development of saline efflorescence) and physical compatibility (different behaviour towards water both in liquid and vapour form).
Nevertheless, in some cases, the interventions are characterized by a greater attention to conservation issues.

While attempting to improve the performance of the buildings and make them consistent with the changing needs of users, the external finishes, the characteristics of the openings, some fixtures, are preserved along with the identity of the architectural artefacts.

Interesting in this sense are the examples of Figures 16 and 17. In the first case, the intervention aimed at ensuring the re-use of the building was carried out without changing the characteristics of the masonry surface and of the roof, whose thickness was not altered.

In order to solve the problems due to the lack of light in the interior, windows were replaced adopting thin window frames (Figure 16).

Preservation of the external wall surfaces and their stratifications, as well as of the finishing elements (such as the access portal) characterise also the intervention shown in Figure 17.

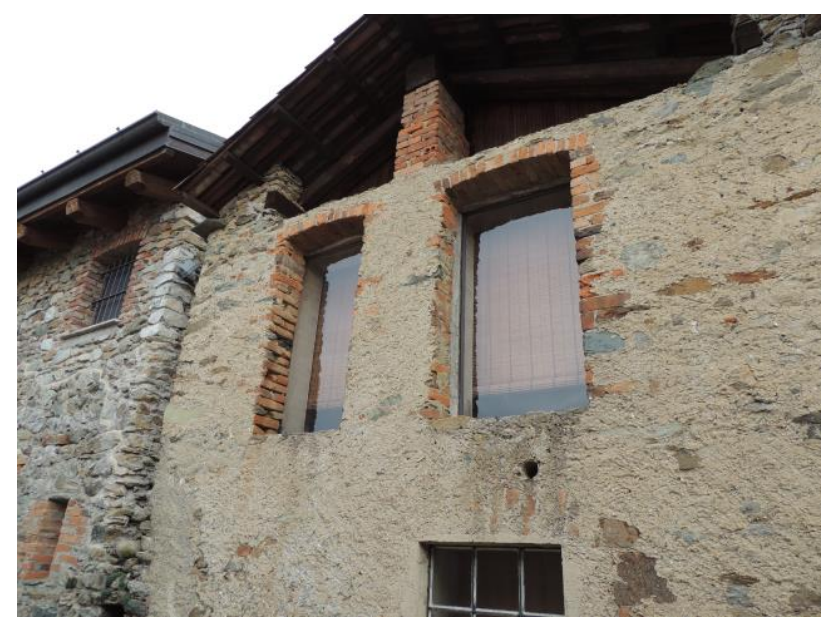

Figure 16. Building F - Intervention preserving both the external masonry surfaces and the roof (credits Silvia Rescic).

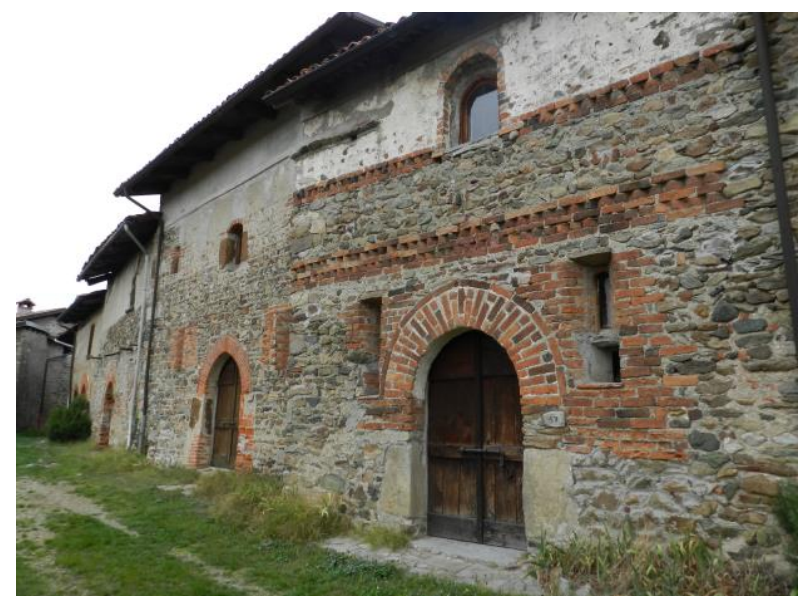

Figure 17. Building $\mathrm{H}$ - Preservation of the surface of the external wall and of the access portal (credits Silvia Rescic).

\section{CONCLUSIONS}

The interventions carried out in the Magnano hamlet highlights how sometimes operations on the buildings seem to take into account mainly functional rather than conservative requests. 
The need to intervene on the architectural heritage transforming the constraints imposed by the latter into «a design opportunity that enriches the restoration, raising the quality and increasing the opportunities for dialogue between the ancient building and our contemporary language» is widely shared among the architectural restoration theorists (Picone, 2004). However, the examination of the operating practice denounces the risk still affecting the architectural heritage.

Replacement, reintegration and integration are carried out without paying enough attention to the constructions and their specific characteristics. Functional adaptation or energy efficiency operations are carried out favouring the achievement of high performance standards rather than the design of compatible interventions. It is not a matter of denying the possibility to intervene through transformations or additions, nor of promoting the absolute intangibility of the existing, but of advocating a congruent design that provides for a «careful study of the needs expressed by users and of the possible alternatives for their satisfaction in agreement with the characteristics of the architecture» (Pagliuca, 2017). As stated by Marco Ermentini, «maybe the time has come to stop behaving violently by distributing slaps and to change our attitude learning to use the secret of caress which is the precious gift of making things awaken" (Ermentini, 2019). This result can be pursued by promoting both the acquisition of greater awareness about the historical-cultural value of the inherited architectural heritage, and the realization of interventions respectful of the identity characteristics of the latter. As far as re-use is concerned, Stefano Della Torre suggests to choose the new utility of the built on the basis of what it can provide, minimizing the change and taking into account the recognised values (Della Torre, 2019). A coevolution approach rather than an adaptive one is promoted. When the introduction of a new different utility is necessary, the requirements should be compliant with what the building can provide respecting its testimonial value.

The article is the result of the authors' joint work. In particular, Manuela Mattone is the author of paragraph 1 and 2.1, Fabio Fratini and Silvia Rescic are authors of paragraph 2.2. The conclusions were written jointly.

\section{REFERENCES}

AA.VV. 2014: VERSUS: Heritage for Tomorrow-Vernacular knowledge for sustainable architecture, Mariana Correia, Letizia Dipasquale, Saverio Mecca (Eds), Firenze University Press.

Acar Bilgin E., 2019: Rural Architectural Characteristics and Conservation Issues of Alaaddinbey Village in Bursa (Turkey), D. Hawkes et al. (eds.), Conservation of Architectural Heritage, Advances in Science, Technology \& Innovation, (C) Springer Nature Switzerland AG 2019

Codice dei Beni Culturali e del Paesaggio, D. Lgs. 22 gennaio 2004 , n. 42 , art. 30

Dipasquale L., Rovero L., Fratini F. 2016: Ancient stone masonry constructions", in Edited by Kent A. Harries and Bhavna Sharma "Nonconventional and Vernacular Construction Materials: characterisation, properties and applications", Elsevier-Woodhead Publishing, 301-332

Dezzi Bardeschi, M., 2002: "Victor Hugo alla prima crociata contro i "restauri"”, Ananke, 33, pp. 6-15.

Ermentini, M. 2019: Il segreto della carezza ovvero ideario di restauro timido. Nardini Editore, Firenze.
Council of Europe. 2005: Framework Convention on the Value of Cultural Heritage for Society (https://www.coe.int/en/web/culture-and-heritage/faroconvention)

Della Torre, S. 2019: "A coevolutionary approach to the re-use of built cultural heritage", atti del $35^{\circ}$ Convegno di studi su Scienza e Beni Culturali: "Il patrimonio culturale in mutamento: le sfide del riuso", Bressanone 1-5 luglio 2019, pp. 25-34.

Fratini F., Mattone M., Rescic R. 2019: Re-use of a medieval tower between conservation and transformation", atti del $35^{\circ}$ Convegno di studi su Scienza e Beni Culturali: "Il patrimonio culturale in mutamento: le sfide del riuso", Bressanone 1-5 luglio 2019, pp. 411-420.

Musso S.F. and Franco G. 2015: Guidelines for sustainable rehabilitation of the rural architecture, in "Vernacular architecture: toward a sustainable future", Mileto, VegaS, Garcia Soriano \& Cristini (Eds), Taylor \& Francis Group, London, pp. 531-536

Pagliuca, A. 2017: Compatibilità, in Dezzi Bardeschi, C.: Abbeceddario minimo. Cento voci per il restauro. Altralinea, Firenze.

Philokyprou M. 2018. Conservation of Vernacular Dwellings. Matters of Authenticity and Sustainability. In: Koui M., Zezza F., Kouis D. (eds) 10th International Symposium on the Conservation of Monuments in the Mediterranean Basin. MONUBASIN 2017. Springer, Cham

Picone, R., 2004: Conservazione e accessibilità. Il superamento delle barriere architettoniche negli edifici e nei siti storici. Arte Tipografica editrice, Napoli.

Prajnawrdhi T.A. 2020. Transformation Versus Preservation of Vernacular Architecture in Bali: A Lesson from Bali Aga Villages. In: Suartika G., Nichols J. (eds) Reframing the Vernacular: Politics, Semiotics, and Representation. Springer, Cham

Settia, A., 1976: "Fortificazioni collettive nei villaggi medievali dell'alta Italia: ricetti, villeforti, recinti, "Bollettino bibliografico storico subalpino", XXIV, pp. 527-617.

Sulfaro, N. 2018: L'architettura come opera aperta. Il tema dell'uso nel progetto di conservazione, ArcHistoR EXTRA 2.

Vassallo, E., 2007: Architettura e architetture, in Ferlenga, A., Vassallo, E., Schellino, F. (a cura di): Antico e Nuovo. Architettura e Architetture, Atti del Convegno (Venezia 31 marzo-3 aprile 2004). Il, Poligrafo, Venezia, p. 23.

Vegas F., Mileto C., 2015: $0 \mathrm{~km}$ conservation, "Vernacular architecture: toward a sustainable future", Mileto, VegaS, Garcia Soriano \& Cristini (Eds), Taylor \& Francis Group, London, pp.737-740

Vegas, F., Mileto, C., 2007: Renovar conservando. Manual para la restauracion de la arquitectura rural del Rincón de Ademuz. Manocomunidad Rincón de Ademuz.

Viglino Davico, M., 1978: I ricetti, difese collettive per gli uomini del contado nel Piemonte medioevale. Edialbra, Torino, pp. 154-161. 